\title{
ASSESSMENT OF ANTIOXIDATIVE AND AMELIORATIVE POTENTIAL OF AQUEOUS EXTRACT OF LEAVES OF THUJA ORIENTALIS (PLATYCLADUS ORIENTALIS [L.])
}

\author{
SUKANYA MEHRA, SHELLY SHARMA, POOJA CHADHA* \\ Department of Zoology, Cytogenetics Laboratory, Guru Nanak Dev University, Amritsar - 143 005, Punjab, India. \\ Email: poojachadha77@yahoo.co.in
}

Received: 30 June 2018, Revised and Accepted: 06 August 2018

\section{ABSTRACT}

Objective: The main objective of the present study is to assess the antioxidative and attenuating potential of aqueous extract of leaves of Thuja orientalis (AET) against the genotoxicity induced by chlorpyrifos (CPF) (0,0-diethyl 0-(3,5,6-trichloro-2-pyridyl) phosphorothioate).

Methods: Phytochemical analysis of the extract was performed to reveal the presence of various bioactive compounds. Free radical scavenging activity was assessed using 2, 2-diphenyl-1-picrylhydrazyl (DPPH) assay and further genoprotective activity of AET was evaluated by in vivo studies using rat as model. For this purpose, male healthy rats, 8-10 weeks old, weighing $120 \pm 10 \mathrm{~g}$, were selected and divided into three groups, namely Group 1 fed with corn oil, taken as control, Group 2 fed with CPF, and Group 3 treated with AET 1 week before CPF exposure. $1 / 4$ of LD ${ }_{50}$, i.e., 38 mg/kg CPF was used for experiment and was orally administered to rats.

Results: The presence of bioactive compounds such as saponins, alkaloids, flavonoids, and terpenes was confirmed by phytochemical analysis. DPPH assay revealed the $\mathrm{IC}_{50}$ value which was deduced to be $205.04 \mu \mathrm{l} / \mathrm{ml}$. In vivo study including exposure to pesticide alone for $24 \mathrm{~h}$, $48 \mathrm{~h}$, and $72 \mathrm{~h}$ showed significant increase in DNA damage ( $\mathrm{p} \leq 0.01$ ) in liver, kidney, and blood as compared to control. However, a dose of AET $400 \mathrm{mg} / \mathrm{kg}$ p.o. given 1 week before each duration of CPF exhibited significant protection from CPF-induced genotoxicity.

Conclusion: Thus, the study suggests the positive effect of aqueous leaf extract of T. orientalis in ameliorating the damage induced by pesticide exposure.

Keywords: Thuja, Chlorpyrifos, Antioxidant, Genoprotective.

(c) 2018 The Authors. Published by Innovare Academic Sciences Pvt Ltd. This is an open access article under the CC BY license (http://creativecommons. org/licenses/by/4. 0/) DOI: http://dx.doi.org/10.22159/ajpcr.2018.v11i12.28205

\section{INTRODUCTION}

The excessive exposure to free radicals and other reactive oxygen species (ROS) has made our body highly susceptible to ROS-mediated tissue and genetic damage. Generation of these free radicals causes lipid peroxidation, DNA damage, and may lead to carcinogenesis [1]. Therefore, to counteract the effect, antioxidants generated inside the body quench the free radicals and prevent the oxidation of substrates, thus preventing oxidative stress and DNA damage. Exposure to various environmental and food contaminants resulted in shifting of the balance toward the accumulation of free radicals, necessitating the need of dietary supplements rich in antioxidants. Plants being highly rich in metabolites that are involved in resisting the generation of free radicals are considered to be best source of antioxidant dietary supplements. Several plants and their isolates have been reported to possess various antioxidants $[2,3]$ and thus prevent the loss of DNA integrity induced by genotoxicants [4].

Thuja orientalis currently known as Platycladus orientalis (L.) is one of the herbs belonging to family Cupressaceae is native to China, Korea, and Russian Far East and is widely cultivated as ornamental plant. Due to the presence of various medicinal uses, the plant is also denoted as tree of life. As the foliage is rich in Vitamin C, Thuja is identified as cure against scurvy during the $16^{\text {th }}$ century [5]. It has been used to cure uterine carcinomas, amenorrhea, and rheumatism [6]. It is reported to contain many bioactive compounds including $1.4-4 \%$ essential oils, flavonols, coumarins, and tannic acid $[7,8]$. Studies confirmed the presence of monoterpenes and diterpenes in cell culture of Thuja showing thujone-rich fraction possessing anticancer activity against A375 cells [9]. It is also found to possess the hepatoprotective [10], antibacterial [11], and antifungal activities [12]. Thuja has also been reported to possess potential to inhibit the activity of HIV-1 virus and common cold virus [6] and its protective effect against toxicity induced by radiation is also reported [13]. Despite being considered as moderately hazardous to humans by the World Health Organization, chlorpyrifos (CPF) is one of the most commonly used organophosphate pesticides used in industrial and domestic applications, particularly in countries such as India, Pakistan, and China. It is the fourth highest consumed insecticide after monocrotophos, acephate, and endosulfan in India [14]. The adverse effects of CPF are assigned to the irreversible inhibition of enzyme acetylcholinesterase (AchE) which leads to the accumulation of acetylcholine, thus inhibiting the smooth transmission of nerve impulses [15]. Along with inhibition of AchE, it also induces oxidative stress, leading to the generation of free radicals which leads to lipid peroxidation, protein oxidation [16], and DNA damage [17]. Exposure beyond the recommended levels has been reported to induce the neurological effects and autoimmune disorders [18]. Thus, CPF is one of the highly concerned pesticide.

Although the number of activities has been found to be possessed by $T$. orientalis, yet the genoprotective activity is scarcely explored. Therefore, the present study aimed to evaluate the antioxidant and ameliorative potential of $T$. orientalis against CPF-induced genotoxicity in different organs of rat.

\section{METHODS}

\section{Chemicals}

CPF (99\%) was purchased from Sigma-Aldrich, St Louis, US, while all other chemicals were of analytical grade purchased from Hi-Media Research Laboratory, Mumbai, India. 


\section{Animals and care}

Sexually mature male rats weighing $110 \pm 20 \mathrm{~g}$ were kept in cages at room temperature $\left(25 \pm 2^{\circ} \mathrm{C}\right)$ with relative humidity of $50-60 \%$ on a $12 \mathrm{~h}$ light-dark cycle and were fed with commercial pellet diet and water ad libitum. The experiments were conducted as per the guidelines of Committee for the purpose of Control and Supervision of Experiments on Animals number 226/CPCSEA2013/20. Animals were acclimated 15 days before the experiment.

\section{Procurement of plant material}

The leaves of T. orientalis collected from trees growing in GNDU campus, Amritsar, and were identified by Herbarium of Department of Botanical and Environmental Sciences, G.N.D.U., Amritsar. The specimen was submitted to herbarium with reference no. 820 , dated: 5/6/2018.

\section{Preparation of plant extract}

The leaves of $T$. orientalis were thoroughly washed in water by adding $0.2 \%$ of sodium hypochlorite. The preparation of extract was done by shade drying and grinding process to obtain homogenate sample. The prepared powder was soaked in distilled water (plant material to solvent ratio was $1: 10, \mathrm{w} / \mathrm{v}$ ) and extracted for 3 hours in orbit shaker at $30^{\circ} \mathrm{C}$ at $230 \mathrm{rpm}$. The supernatant collected was filtered using Whatman No.1, pooled, and concentrated at room temperature. The concentrated extract was further lyophilized and kept at $4^{\circ} \mathrm{C}$ for further use.

\section{Preliminary phytochemical analysis}

Plant extract was evaluated for the presence of flavonoids, alkaloids, saponins, and terpenes [19] using the following protocols

\section{Saponins}

$1 \mathrm{ml}$ of the stock solution of extract in a test tube was shaken vigorously for $2 \mathrm{~min}$. Frothing observed indicates the presence of saponins.

\section{Alkaloids}

2 drops of Wagner's reagent was added to $1 \mathrm{ml}$ of stock solution of extract. A reddish-brown precipitate observed indicates the presence of alkaloids in extract.

\section{Flavonoids}

$1 \mathrm{ml}$ of $10 \% \mathrm{NaOH}$ was added to $3 \mathrm{ml}$ of stock solution of extract. A yellow coloration showed the presence of flavonoids.

\section{Terpenes}

$1 \mathrm{ml}$ of acetic anhydride was added to $1 \mathrm{ml}$ of plant extract followed by the addition of $1 \mathrm{ml}$ of concentrated sulfuric acid down the wall of the test tube to form a layer underneath. The test tube was observed for red coloration showing the presence of terpenes.

\section{Determination of antioxidant potential by 2, 2-diphenyl-1- picrylhydrazyl (DPPH) assay}

The antioxidant activities of plant extracts were assessed by method described by Brand-Williams et al. [20]. In this assay, $4 \mathrm{mg}$ DPPH in $100 \mathrm{ml}$ methanol solution was prepared. Different concentrations of sample were prepared in which $1 \mathrm{ml}$ of above solution was added and was left for incubation for $30 \mathrm{~min}$ in dark at room temperature. When DPPH reacts with an antioxidant compound, which can donate hydrogen, it itself gets reduced. The changes in color (from deep violet to light yellow) were read using a spectrophotometer. The optical density was recorded at $517 \mathrm{~nm}$ and percentage inhibition was calculated using the formula given below:

Percent inhibition of DPPH activity $=\frac{\begin{array}{c}\text { Absorbance control } \\ \text {-absorbance sample }\end{array}}{\begin{array}{c}\text { Absorbance } \\ \text { control }\end{array}} \times 100$

Where, absorbance control refers to DPPH+methanol solution without any sample and absorbance sample refers to $\mathrm{DPPH}+$ methanol+sample solution.

\section{In vivo studies}

After range finding, $\mathrm{LD}_{50}$ value for $\mathrm{CPF}$ was found to be $152 \mathrm{mg} /$ kg body weight using probit analysis software [21], $1 / 4$ of $\mathrm{LD}_{50}$, i.e., $38 \mathrm{mg} / \mathrm{kg}$ b.wt CPF (sublethal dose) was used for experiment and was orally administered to rats using gavage. Three groups of rats were taken which include Group 1 as control treated with corn oil, Group 2 treated with CPF in corn oil, and Group 3 pretreated with AET 1 week before CPF exposure. After 24, 48, and $72 \mathrm{~h}$ of exposure, blood, liver, and kidney were collected and used for comet assay.

\section{Determination of genoprotective potential by comet assay}

Alkaline comet assay is a gel electrophoresis method that is used to measure DNA damage using microscope. Blood was collected from heart. The tissues collected after dissection in phosphate-buffered saline solution were homogenized and centrifuged to obtain cells. The cells were placed on the slides along with $1 \%$ low melting point agarose melted at $37^{\circ} \mathrm{C}$, over the slides precoated with $1 \%$ normal melting point agarose. Afterward, the slides were covered by cover glasses for few minutes and then immersed in a lysis solution $(\mathrm{pH}=10.0)$ for $60 \mathrm{~min}$. Then, the slides were put in a weak buffer $(\mathrm{pH}>13.0$, for $20 \mathrm{~min}$ ) and electrophoresis was performed, which was done at $25 \mathrm{~V}$ with an electricity current adjusted to $300 \mathrm{~mA}$. DNA was stained with ethidium bromide $(20 \mu \mathrm{g} / \mathrm{ml})$ for $5 \mathrm{~min}$ and viewed under $\times 400$ magnification using a fluorescence microscope with an excitation filter of 510-560 nm and barrier filter of $590 \mathrm{~nm}$. Individual images were taken and analyzed using CaspLab software for analyzing the percentage tail DNA and olive tail moment.

\section{Statistical analysis}

The data were analyzed using SPSS. The significance of differences was calculated using one-way analysis of variance followed by post hoc Tukey test.

\section{RESULTS}

\section{Preliminary phytochemical analysis}

Phytochemical analysis of the aqueous extract of leaves of $T$. orientalis reveals the presence of saponins, alkaloids, flavonoids, and terpenes as indicated by the preliminary tests.

\section{Determination of antioxidant potential by DPPH assay}

Antioxidants potential of the extract was assessed using DPPH free radical scavenging assay (Fig. 2). The amount of DPPH reduced was quantified by measuring a decrease in absorbance at $517 \mathrm{~nm}$. The AET samples reduced the DPPH radicals and showed antioxidant activity using DPPH. IC ${ }_{50}$ value was calculated by plotting the graph (Fig. 1) and was found to be $205.04 \mu \mathrm{l} / \mathrm{ml}$

\section{Genoprotective potential}

The results revealing the genoprotective activity of $T$. orientalis have been summarized in Fig. 3a-f. The activity was studied by comet assay using the different tissues, namely blood, kidney, and liver of the rat. The parameters such as percentage tail DNA and olive tail moment were considered for assessment. It is clear from the results that treatment with $38 \mathrm{mg} / \mathrm{kg}$ (b.wt) of CPF has resulted in significantly higher DNA damage as compared to control in all the tissues considered. The values of both the parameters of comet assay were found to be increased significantly in all the three tissues considered (post hoc Tukey Test). However, a significant $(\mathrm{p} \leq 0.01)$ decrease in genotoxicity for percentage tail DNA and olive tail moment was observed at the end of the all-time intervals in the group treated with AET 1 week before CPF

Percentage tail DNA was found to be decreased by $53 \%, 60 \%$, and $61 \%$, and olive tail moment was found to be decreased by $60 \%, 53 \%$, and $68 \%$, respectively, in case of blood at 24,48 , and $72 \mathrm{~h}$, respectively. In the 


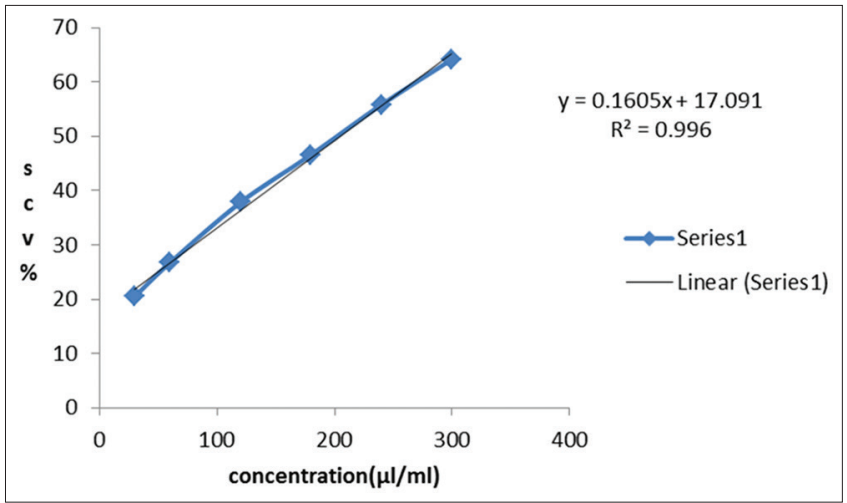

Fig. 1: Graph presenting the equation for $\mathrm{IC}_{50}$ value

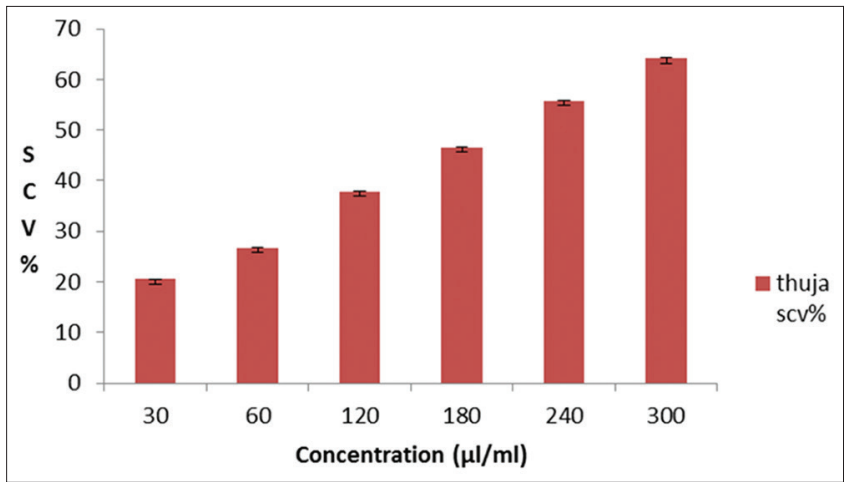

Fig. 2: 2, 2-diphenyl-1-picrylhydrazyl scavenging activity

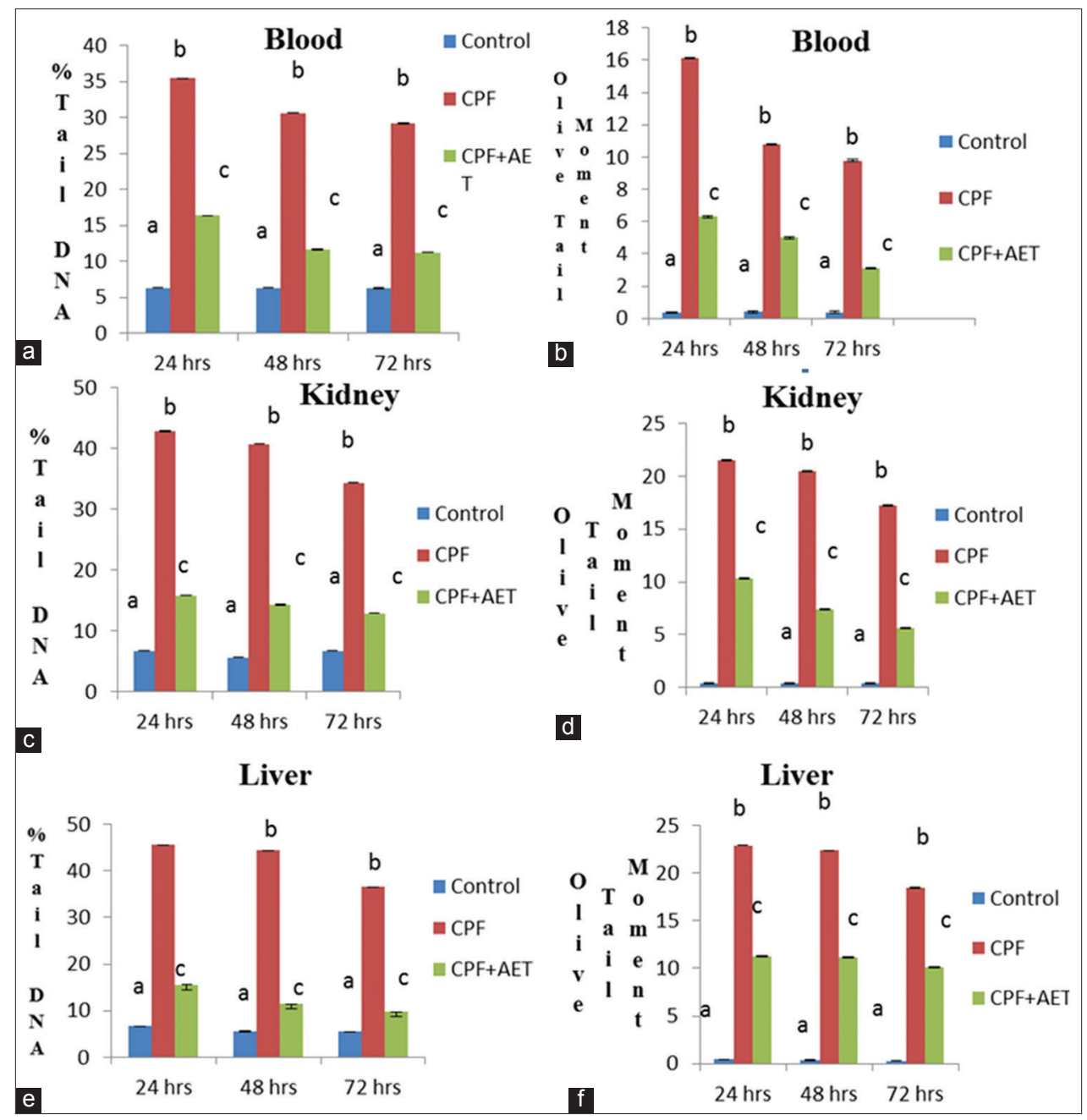

Fig. 3: (a-f) Percentage tail DNA and olive tail moment in all the treatment groups at different hours of exposure in different tissues. Results are shown with mean \pm standard error. Means that do not share common letters are significantly different. Different letters a, $b$, and c signify the effect of treatment

case of kidney, percentage tail DNA was found to be decreased by $63 \%$, $64 \%$, and $61 \%$, and olive tail moment was decreased by $51 \%, 64 \%$, and $67 \%$, respectively, at 24,48 , and $72 \mathrm{~h}$, and in case of liver, percentage tail DNA was found to be decreased by $65 \%, 74 \%$, and $73 \%$, and olive tail moment was decreased by $51 \%, 49 \%$, and $45 \%$, respectively, at 24,48 , and $72 \mathrm{~h}$. Hence, overall, the percent reduction in all the parameters in different tissues was more than $50 \%$ and up to $74 \%$.

\section{DISCUSSION}

Organophosphate pesticides are one of the highly concerned compounds that have been most widely used in developing countries; therefore, concerns regarding the negative impact of these chemicals to environment and human health are being enhanced. CPF, an organophosphate insecticide used in both agriculture and domestic domains, is suspected to produce very serious toxic effects in humans 
as high concentration of it has been detected in vegetables, fruits, and human breast milk in Punjab, India [22]. It has also been found to induce immunological abnormalities [23] and decreased sperm count and mobility [24]. During the present investigation, CPF was found to have genotoxic potential as revealed by significant increase in percentage tail DNA and OTM in all the three tissues of rats as compared to controls. Earlier studies suggested that both acute and chronic intoxication by pesticides including CPF lead to the induction of oxidative stress by generating ROS which may further attack lipids, proteins, and DNA, causing oxidation and membrane damage, enzyme inactivation, and even cell death or cancer $[1,25,26]$. The increased ROS attacks the biomolecules like DNA resulting in increase in DNA damage, as observed in the present study.

The aim of the present study is to depict the ameliorative effect of AET on the DNA damage, induced by CPF in rats. Significant reduction in the percentage tail DNA and olive tail moment was observed in the group pretreated with AET. Similarly, supplementation of Thuja extract has been earlier reported to reduce the toxic effects induced by $\mathrm{CCl}_{4}$ and benzo(a) pyrene $[10,27]$. In the present study, AET was found to show high free radical scavenging activity, assessed by DPPH assay revealing $\mathrm{IC}_{50}$ to be $205.04 \mu \mathrm{l} / \mathrm{ml}$. Hence, high DPPH radical scavenging activity indicates the antioxidant potential of Thuja extract, and as a result, it prevents the formation of free radicals, leading to the reduction in DNA damage as observed in the present observation. Recently Daryoush et al. [28], revealed the antioxidant and antihemolytic effect of leaves of T. orientalis revealing the potential to reduce free radicals. Among all the leaf extracts prepared in methanol, ethanol, ethyl acetate, and water, the water extract showed the highest antioxidant and antihemolytic activity. Thuja occidentalis is reported to possess antioxidative and antiproliferative components including alpha-thujone, beta-thujone, and other bioactive compounds such as flavonols, tannic acid, saponins, monoterpenes, and diterpenes, which all are considered as free radical scavengers [7]. Phytochemical studies performed during the present study also reveal the presence of saponins, alkaloids, flavonoids, and terpenes.

Therefore, the presence of bioactive compounds and high free radical scavenging activity might be contributing for the genoprotective potential of aqueous extract of leaves of T. orientalis.

\section{CONCLUSION}

The AET is found to reduce the pesticide-induced DNA damage by virtue of its antioxidant potential and the bioactive compounds present in it. Hence, it can be used as natural antioxidants rich food supplement.

This is preliminary study and further studies to find out main bioactive compound in AET are needed.

\section{ACKNOWLEDGEMENT}

The authors are thankful to UGC-SAP (University Grants Commission - Special Assistance Program) and C.P.E.P.A (Centre with Potential for Excellence In Particular Area) for providing financial assistance and the Head, Department of Zoology for providing necessary laboratory facilities.

\section{AUTHORS' CONTRIBUTIONS}

The present study is designed by Dr Pooja Chadha and the experiments are performed by Sukanya Mehra and Shelly Sharma. Data analysis and manuscript preparation are done by Sukanya Mehra.

\section{CONFLICTS OF INTEREST}

The authors declare that they have no conflicts of interest.

\section{REFERENCES}

1. Zama D, Meraihi Z, Tebibel S, Benayssa W, Benayache F, Benayache S, et al. Chlorpyrifos-induced oxidative stress and tissue damage in the liver, kidney, brain and fetus in pregnant rats: The protective role of the butanolic extract of Paronychia argentea. Indian J Pharm 2007:39:145-50

2. Khan MS, Yusufzai SK, Ying LY, Zulnashriq W. GC-MS based chemical profiling and evaluation of antioxidant potential of leaves and stems of Alternanthera sessilis red from Sabah, Malaysia. Int J Pharm Pharm Sci 2018;10:4-9.

3. Balakrishnan BB, Krishnasamy K. Evaluation of free radical screening and antioxidant potential of Moringa concanensis nimmo-a medicinal plant used in Indian traditional medication system. Int J Pharm Pharm Sci 2018;10:91-7.

4. Fierascu I, Ungureanu C, Avramescu SM, Cimpeanu C, Georgescu MI, Fierascu RC, et al. Genoprotective, antioxidant, antifungal and anti-inflammatory evaluation of hydroalcoholic extract of wild-growing Juniperus communis L. (Cupressaceae) native to Romanian Southern Sub-Carpathian hills. BMC Complement Altern Med 2018;18:3.

5. Durzan DJ. Arginine, scurvy and cartier's "tree of life". J Ethnobiol Ethnomed 2009;5:5.

6. Tsiri D, Graikou K, Pobłocka-Olech L, Krauze-Baranowska M, Spyropoulos C, Chinou I, et al. Chemosystematic value of the essential oil composition of Thuja species cultivated in Poland-antimicrobial activity. Molecules 2009; 14:4707-15.

7. Chang LC, Song LL, Park EJ, Luyengi L, Lee KJ, Farnsworth NR, et al. Bioactive constituents of Thuja occidentalis. J Nat Prod 2000;63:1235-8

8. Naser B, Bodinet C, Tegtmeier M, Lindequist U. Thuja occidentalis (Arbor vitae): A Review of its pharmaceutical, pharmacological and clinical properties. Evid Based Complement Alternat Med 2005;2:69-78

9. Biswas R, Mandal SK, Dutta S, Bhattacharyya SS, Naoual B, KhudaBukhsh AR. Thujone-rich fraction of Thuja occidentalis demonstrates major anti-cancer potentials: Evidences from in vitro. Evid Based Complement Alternat Med 2011;568148:16.

10. Dubey SK, Batra A. Hepatoprotective activity from ethanol fraction of Thuja occidentalis Linn. Asian J Res Chem 2008;1:32-5.

11. Yogesh K, Ali J. Antioxidant potential of Thuja (Thuja occidentalis) cones and peach (Prunus persia) seeds in raw chicken ground meat during refrigerated $\left(4 \pm 1^{\circ} \mathrm{C}\right)$ storage. J Food Sci Technol 2014;51:1547-53.

12. Sah SN, Regmi S, Tamang M. Antibacterial effects of Thuja leaves extract. Int J Appl Sci Biotechnol 2017;5:256-60.

13. Sunila ES, Kuttan G. Protective effect of Thuja occidentalis against radiation-induced toxicity in mice. Integr Cancer Ther 2005;4:322-8.

14. Ansaruddin PA, Vijayalakshmi K. The womb is not safe anymore. Ind Agr News 2003;2:3

15. Člović MB, Vasić VM, Avramović NS, Gajić MM, Djurić DM, Krstić DZ, et al. In vitro evaluation of neurotoxicity potential and oxidative stress responses of diazinon and its degradation products in rat brain synaptosomes. Toxicol Lett 2015;233:29-37.

16. Malla FA. Assessment of total protein concentration in liver of fresh water fish, Channa punctuates (bloch) with special reference to an organophosphate insecticide, chlorpyrifos. Int $\mathrm{J}$ Pharma Bio Sci 2012;3:B567-71

17. Ali D, Nagpure NS, Kumar S, Kumar R, Kushwaha B. Genotoxicity assessment of acute exposure of chlorpyrifos to freshwater fish Channa punctatus (Bloch) using micronucleus assay and alkaline single-cell gel electrophoresis. Chemosphere 2008;71:1823-31.

18. Saunders M, Magnanti BL, Correia Carreira S, Yang A, AlamoHernández U, Riojas-Rodriguez $\mathrm{H}$, et al. Chlorpyrifos and neurodevelopmental effects: A literature review and expert elicitation on research and policy. Environ Health 2012;11 Suppl 1:S5.

19. Olusola A, Olutayo O, Michael A, Olakunle F, Edah AO. Elemental analysis and anti-microbial potentials of the leaf extract of Cassia arereh. Int Res J Pharm Pharm 2011;1:188-93.

20. Brand-Williams A, Cuvelier ME, Berset C. Use of a free radical method to evaluate antioxidant activity. Lebensm-Wiss. u.-Technol $1995 ; 28: 25-30$

21. Sharma S, Chadha P. Induction of neurotoxicity by organophosphate pesticide chlorpyrifos and modulating role of cow urine. Springerplus 2016;5:1344

22. Bedi JS, Gill JP, Aulakh RS, Kaur P, Sharma A, Pooni PA, et al. Pesticide residues in human breast milk: Risk assessment for infants from Punjab, India. Sci Total Environ 2013;463-464:720-6.

23. Jack D, Thrasher PD, Madison R, Broughton A. Immunologic abnormalities in humans exposed to chlorpyrifos: Preliminary observations. Arch Environ Health 2010;45:89-93.

24. Umosen AJ, Ambali SF, Ayo JO, Mohammed B, Uchendu C. Alleviating effects of melatonin on oxidative changes in the testes and pituitary glands evoked by subacute chlorpyrifos administration in wistar rats. 
Asian Pac J Trop Biomed 2012;2:645-50

25. Roszczenko A, Rogalska J, Moniuszko-Jakoniuk J, Brzóska MM. The effect of exposure to chlorfenvinphos on lipid metabolism and apoptotic and necrotic cells death in the brain of rats. Exp Toxicol Pathol 2013;65:531-9.

26. Mansour SA, Mossa HT. Lipid peroxidation and oxidative stress in rat erythrocytes induced by chlorpyrifos and the protective effect of zinc. Pest Biochem Physiol 2009;93:34-9.
27. Mukherjee A, Sikdar S, Khuda-Bukhsh AR. Evaluation of ameliorative potential of isolated flavonol fractions from Thuja occidentalis in lung cancer cells and in Benzo(a)pyrene induced lung toxicity in mice. J Tradit Complement Med 2016;1:1-13

28. Daryoush HA, Malihe AS, Mohadjerani M, Ferns GA, Amir A. Prooxidant-antioxidant balance and antioxidant properties of Thuja orientalis L: A potential therapeutic approach for diabetes mellitus. Curr Mol Pharmacol 2018;11:109-12. 